\title{
The Effect of Anxiety on the Smooth Production of Breast Milk in Postpartum Mother in COVID-19 Pandemic
}

\author{
Christin Jayanti \\ Gatot Soebroto College of Health Sciences, Indonesia \\ Corresponding authoremail: christin_jayanti@yahoo.co.id \\ Devi Yulianti \\ Gatot Soebroto College of Health Sciences, Indonesia \\ Email: deviyulianti794@gmail.com
}

\begin{abstract}
The COVID-19 pandemic makes mothers who are about postpartum experience anxiety from mild to moderate such as fear in the crowd and confine themselves at home. So that it affects the production of breast milk of postpartum mothers, due to the increase in cortisol makes the inhibition of the transportation of the hormone oxytocin in its secretion so that the production of breast milk is inhibited. To identify the influence of anxiety on the smooth production of breast milk in mothers in the COVID-19 pandemic at RSPAD Gatot Soebroto. This type of research is an analytic survey using a cross-sectional design. The sample was a postpartum mother on the 2 nd Floor of PIS RSPAD Gatot Soebroto numbered 35 people. Analyze the data using Chi-Square. There is an influence of COVID-19 pandemic anxiety on the production of postpartum mothers' breast milk (p-value: $0.000<\alpha: 0.05)$. It is recommended for postpartum mothers to always think positively and seek information about health, especially COVID-19, or do relaxation so as not to worry.
\end{abstract}

Keywords---anxiety, breast milk, COVID-19, fluency, postpartum mother

\section{Introduction}

The postpartum period (puerperium) is the period after the birth of the placenta and ends when the bladder returned to the state before pregnancy. This postpartum period lasts 6 weeks or \pm 40 days. The postpartum period is a critical period for both mother and baby. Changes that occur during the postpartum period are physical, uteri involution, lactation and production of breast milk, changes in the mother's body system, and psychic changes (Yuliana \& Hakim, 2020). Breast milk is a white liquid produced by the mother's breast glands through the lactation process. Breast milk contains all the nutrients the baby needs and protective substances from various germs.

According to the World Health Organization (WHO) recommends that babies should only be given breast milk for at least the first 6 months after the baby is born to achieve optimal growth, development, and health. Optimal breastfeeding is so important that it can save the lives of more than 820,000 children under five and can prevent the addition of 20,000 cases of breast cancer each year (World Health Organization, 2020). According to WHO 2015, the coverage of exclusive breastfeeding in the world is only $40 \%$. In Asia, the coverage of exclusive breastfeeding with the highest coverage is in South Asia at 55\%, while the lowest coverage is in Asia Pacific, West Africa, and Eastern Europe at 30\%. This is not in accordance with who's the target of increasing exclusive breastfeeding in the first 6 months to at least 50\%. This is who's the fifth target by 2025 (Nurhidayati et al., 2021).

The Government of Indonesia has established a national policy related to the exclusive breastfeeding program contained in Government Regulation of the Republic of Indonesia Number 33 of 2012, which states that breast milk is the best source of nutrition that can improve the health of mothers and children. Breast milk is given to the baby from birth for six months, without adding and/or replacing it with other foods or drinks (except drugs, vitamins, and minerals). According to Health Law No. 36 of 2009, during the provision of breast milk, the family, government, 
local government, and the community must fully support the mother with the provision of special time and facilities (Kusumaningrum \& Sari, 2021).

According to Riskesdas data taken from 2014 - 2018 exclusive breast milk coverage in Indonesia in 2014 amounted to $37.3 \%, 2015$ by $55.7 \%$, in 2016 by $54 \%$, in 2017 by $61.33 \%$, and in 2018 there was a significant decrease of $37.3 \%$. When compared to the target set by the Ministry of Health of Indonesia which is $80 \%$, the achievement of exclusive breast milk at the Indonesian level still has not met the target (Nurhidayati et al., 2021). Factors that affect the failure of breastfeeding are often caused by the onset of several factors, including sociocultural changes, psychological factors, maternal physical factors, increased promotion of formula, health workers' factors, maternal food, baby birth weight, contraceptive use. The smoothness of breast milk is strongly influenced by psychiatric factors because the mother's feelings can inhibit or increase oxytocin expenditure, anxious mothers will spend less than mothers who are not anxious (Kusumaningrum \& Sari, 2021).

Coronavirus Disease 2019 (COVID-19) has been declared by WHO as a global pandemic and in Indonesia is declared a type of disease that causes public health emergencies and non-natural disasters, which not only cause death but also cause considerable economic losses, so that countermeasures including prevention and control are needed (Decree of the Minister of Health of the Republic of Indonesia, 2020). The COVID-19 pandemic caused many restrictions on almost all routine services, both access, and quality, including restrictions in maternal and neonatal health services, such as reduced frequency of pregnancy screenings and delays in classes of pregnant women (Yuliaty et al., 2021; Anisha et al., 2021).

These conditions can cause problems during pregnancy and postpartum because it is a vulnerable time for the mother, while psychological distress can be negative for the mother and her baby. Studies show that higher symptoms of anxiety and depression in pregnant women during prenatal anxiety and depression can lead to changes in physical activity, nutrition, sleep patterns, maternal mood, and fetal health that can increase the risk of miscarriage, premature birth, low birth weight, and lower apgar scores at birth (Demissie \& Bitew, 2021).

From the results of a preliminary study conducted on the 2nd Floor of PIS RSPAD GAtot Soebroto through interviews with 7 mothers of postpartum mothers, it was obtained as many as 4 postpartum mothers (57\%) experienced anxiety, anxiety, unsettled after childbirth and the first breast milk expenditure was slow (>2 days) (Perzow et al., 2021; An et al., 2021; Goodman et al., 2016). Then as many as 3 postpartum mothers (42\%) did not experience anxiety after childbirth and rapid first breast milk production ( $\leq 2$ days). Based on the background above researchers want to know the effect of anxiety on the smooth production of breast milk in postpartum mothers in the COVID-19 pandemic at Gatot Soebroto Hospital.

\section{Research Methods}

This type of research survey analytics cross-sectional design. The population of postpartum mothers in Gatot Soebroto Hospital is 35 people. The sampling technique is nonprobability sampling with total sampling so that the sample is taken throughout the population (Zhou et al., 2021; Mulyani et al., 2017; Brockington, 2004). Analysis data of chi-square test. The characteristics of postpartum mothers on the 2nd floor of PIS RSPAD Gatot Soebroto based on the age of the most dominant respondents are the age of 20-35 years as many as 22 people (62.9\%). Based on the most dominant respondent parity is multipara parity as many as 26 people $(74.3 \%)$. Based on the work of the most dominant respondents as a housewife as many as 20 people $(57.1 \%)$. Based on the most dominant type of labor is labor with c-section as many as 18 respondents $(51.4 \%)$.

Tabel 1

The effect of anxiety on the smooth production of breast milk during the COVID-19 pandemic on the 2nd floor of PIS RSPAD Gatot Soebroto

\begin{tabular}{|c|c|c|c|c|c|c|c|c|}
\hline \multirow{3}{*}{ No. } & \multirow{3}{*}{$\begin{array}{l}\text { Breast Milk } \\
\text { Production }\end{array}$} & \multicolumn{4}{|c|}{ Anxiety during pandemic COVID-19 } & \multirow{2}{*}{\multicolumn{2}{|c|}{ Total }} & \multirow{3}{*}{ P-Value } \\
\hline & & \multicolumn{2}{|c|}{ Axious } & \multicolumn{2}{|c|}{ Not Worried } & & & \\
\hline & & $\mathrm{N}$ & $\%$ & $\mathrm{~N}$ & $\%$ & $\mathrm{~N}$ & $\%$ & \\
\hline 1. & No & 21 & $60 \%$ & 5 & $14,3 \%$ & 28 & $74,3 \%$ & .000 \\
\hline 2. & Yes & 1 & $2,9 \%$ & 8 & $22,9 \%$ & 9 & $25,7 \%$ & \\
\hline Total & & 22 & $62,9 \%$ & 13 & $37,1 \%$ & 35 & $100 \%$ & \\
\hline
\end{tabular}


It is known that the value of p-value $0.000<0.005$ means that there is a significant influence of postpartum mother anxiety on the smooth production of breast milk during the COVID-19 pandemic on the 2nd floor of PIS RSPAD Gatot Soebroto.

\section{Results and Discussion}

Based on the results of the study it is known that of the 28 breast milk people who did not come out, the highest proportion of anxiety about the COVID-19 pandemic amounted to 21 people (60\%), but some did not come out who were not worried about the COVID-19 pandemic amounted to 5 people (14.3\%). As for the 9 breast milk people out, the highest proportion in not anxious COVID-19 pandemic amounted to 8 people (22.9\%), but some came out experiencing anxiety about the COVID-19 pandemic amounted to 1 person (2.9\%) (Peng et al., 2020; GonzalezGarcia et al., 2021). The results of the statistical test obtained the results of p-value: $0.000<\alpha: 0.05$ so that Ho was rejected and Ha accepted that there was an influence of anxiety pandemic COVID-19 on the expenditure of breast milk mother postpartum at RSPAD Gatot Soebroto. This is in line with the research Pri Hastuti1 2020 conducted Mother ATHAHIRA Healthy House with cross-section method as many as 30 people with sampling techniques nonprobability sampling and instruments used in the form of questionnaires where the results of the study There is an anxiety influence COVID-19 pandemic on postpartum maternal breast milk expenditure (p-value: $0.000<\alpha: 0.05$ ).

Aryani \& Afrida (2021), Expresses that anxiety is a concern due to a perceived threat to health. Health concerns and anxiety associated with epidemics or pandemics can have significant psychological impacts e.g., stress, disturbing negative thoughts, avoidance. Expressing that anxiety is a natural disorder of feelings characterized by feelings of fear or deep and ongoing worry. The period of pregnancy, childbirth, and postnatal is a period of severe stress, anxiety emotional disorders, and adjustment (Susilo et al., 2020; Wahyudi et al., 2019; Asmariyah et al., 2021). In the process of breastfeeding, there are two important processes, namely the process of milk production reflex and the process of milk production (let down reflex) both of which are influenced by hormones regulated by the hypothalamus. The mental condition and emotions of the mother are calm greatly affect the smoothness of breast milk. If the mother experiences stress, depression, unsettledness, anxiety, sadness, and tense thoughts will affect the smoothness of breast milk. Anxious mothers will be less breast milked than mothers who are not anxious (Mardjun et al., 2019).

Based on the results of research that postpartum mothers experience anxiety marked mother is always agitated, feeling afraid, feeling anxious, feeling unsettled, and always have a bad feeling of fear of contracting COVID-19 in her and her baby Postpartum mother should prepare to breastfeed her baby, but some mothers experience anxiety that affects breast milk expenditure. Breastfeeding mothers should think positively and relax so as not to experience anxiety and the psychological condition of the mother becomes good, good psychological condition can trigger the work of hormones that produce breast milk (De Jager et al., 2014; Lonstein, 2007; Matthey et al., 2003).

Based on the results of research and supporting theories, researchers assume that anxiety occurs in postpartum mothers because they think too much about negative things during the COVID-19 pandemic. Postpartum mothers should think positively, try to love their baby, and relax when breastfeeding. When the mother thinks positively and remains calm will trigger the production of breast milk so that breast milk can come out smoothly, on the contrary, mothers whose psychological conditions are disturbed such as feeling anxious will affect breast milk production so

that breast milk production can decrease and cause breast milk not to come out (Negeri, 2020; Saleh, 2019; Sulaeman et al., 2019; Mulyani, 2018).

\section{Conclusion}

There is an influence of anxiety on the smooth production of breast milk of postpartum mothers with p-value: 0.000 $<\alpha: 0.05$ then it can be concluded that there is a significant influence of anxiety on the smooth production of breast milk in mothers nifas in the pandemic COVID-19 on the 2nd floor of PIS RSPAD Gatot Soebroto.

\section{Acknowledgments}

Acknowledgments are addressed to Gatot Soebroto Army Hospital for allowing the collection of the data needed for this research. and also a big thank you to postpartum mothers who have been willing to be respondents in this research 


\section{References}

An, R., Chen, X., Wu, Y., Liu, J., Deng, C., Liu, Y., \& Guo, H. (2021). A survey of postpartum depression and health care needs among Chinese postpartum women during the pandemic of COVID-19. Archives of psychiatric nursing, 35(2), 172-177. https://doi.org/10.1016/j.apnu.2021.02.001

Anisha, N., Yunarti, F., \& Ahmar, H. (2021). Mengenal Covid-19. Media Sains Indonesia.

Aryani, N. P., \& Afrida, B. R. (2021). Pencegahan Penularan Corona Virus Disease (COVID-19) pada Masyarakat di Lombok Barat. Penerbit NEM.

Asmariyah, A., Novianti, N., \& Suriyati, S. (2021). Tingkat Kecemasan Ibu Hamil Pada Masa Pandemi Covid-19 Di Kota Bengkulu. Journal Of Midwifery, 9(1), 1-8.

Brockington, I. (2004). Postpartum psychiatric disorders. The Lancet, 363(9405), 303-310. https://doi.org/10.1016/S0140-6736(03)15390-1

De Jager, E., Broadbent, J., Fuller-Tyszkiewicz, M., \& Skouteris, H. (2014). The role of psychosocial factors in exclusive breastfeeding to six months postpartum. Midwifery, 30(6), 657-666. https://doi.org/10.1016/j.midw.2013.07.008

Demissie, D. B., \& Bitew, Z. W. (2021). Mental health effect of COVID-19 pandemic among women who are pregnant and/or lactating: A systematic review and meta-analysis. SAGE open medicine, 9, 20503121211026195.

Gonzalez-Garcia, V., Exertier, M., \& Denis, A. (2021). Anxiety, post-traumatic stress symptoms, and emotion regulation: A longitudinal study of pregnant women having given birth during the COVID-19 pandemic. European Journal of Trauma \& Dissociation, 5(2), 100225. https://doi.org/10.1016/j.ejtd.2021.100225

Goodman, J. H., Watson, G. R., \& Stubbs, B. (2016). Anxiety disorders in postpartum women: A systematic review and meta-analysis. Journal of affective disorders, 203, 292-331. https://doi.org/10.1016/j.jad.2016.05.033

Kusumaningrum, A. T., \& Sari, P. I. A. (2021). a Faktor-Faktor Yang Mempengaruhi Pola Menyusui Pada Masa Pandemi Covid-19. Jurnal Ilmiah Kesehatan Media Husada, 10(1), 74-81.

Lonstein, J. S. (2007). Regulation of anxiety during the postpartum period. Frontiers in neuroendocrinology, 28(23), 115-141. https://doi.org/10.1016/j.yfrne.2007.05.002

Mardjun, Z., Korompis, G., \& Rompas, S. (2019). Hubungan Kecemasan Dengan Kelancaran Pengeluaran Asi Pada Ibu Post Partum Selama Dirawat Di Rumah Sakit Ibu Dan Anak Kasih Ibu Manado. Jurnal Keperawatan, 7(1).

Matthey, S., Barnett, B., Howie, P., \& Kavanagh, D. J. (2003). Diagnosing postpartum depression in mothers and fathers: whatever happened to anxiety?. Journal of affective disorders, 74(2), 139-147. https://doi.org/10.1016/S0165-0327(02)00012-5

Mulyani, S. (2018). Work and knowledge of mother readiness in exclusive breastfeeding. International Research Journal of Management, IT and Social Sciences, 5(4), 91-97. https://doi.org/10.21744/irjmis.v5n4.274

Mulyani, S., Subiyanto, A., Anantanyu, S., Respati, S. H., \& Wiboworini, B. (2017). Path analysis: knowledge, motivation factor, and their relationship with readiness to provide exclusive breastfeeding among pregnant women. International Research Journal of Management, IT and Social Sciences, 4(1), 8-14. Retrieved from https://sloap.org/journals/index.php/irjmis/article/view/430

Negeri, T. K. K. D. (2020). Pedoman umum menghadapi PANDEMI COVID-19 bagi pemerintah daerah: pencegahan, pengendalian, diagnosis dan manajemen. Journal of Chemical Information and Modeling, 53(9), 1689-1699.

Nurhidayati, N., Saleha, S., Hanum, Z., \& Agustina, A. (2021). Edukasi Pemberian Asi Ekslusif Pada Ibu Yang Memiliki Bayi Usia 0-6 Bulan Di Masa Pandemi COVID-19 Di Desa Paya Meuneng Kecamatan Peusangan Kabupaten Bireuen Tahun 2021. Jurnal Pengabdian Kepada Masyarakat (KESEHATAN), 3(2), 91-98.

Peng, S., Zhu, H., Yang, L., Cao, L., Huang, X., Dynes, M., ... \& Xia, S. (2020). A study of breastfeeding practices, SARS-CoV-2 and its antibodies in the breast milk of mothers confirmed with COVID-19. The Lancet Regional Health-Western Pacific, 4, 100045. https://doi.org/10.1016/j.lanwpc.2020.100045

Perzow, S. E., Hennessey, E. M. P., Hoffman, M. C., Grote, N. K., Davis, E. P., \& Hankin, B. L. (2021). Mental health of pregnant and postpartum women in response to the COVID-19 pandemic. Journal of affective disorders reports, 4, 100123. https://doi.org/10.1016/j.jadr.2021.100123

Saleh, U. (2019). Anxiety Disorder (Memahami gangguan kecemasan: jenis-jenis, gejala, perspektif teoritis dan Penanganan).

Sulaeman, R., Lina, P., \& Purnamawati, D. (2019). Pengaruh pijat oksitosin terhadap pengeluaran ASI pada Ibu Postpartum primipara. Jurnal Kesehatan Prima, 13(1), 10-17.

Susilo, A., Rumende, C. M., Pitoyo, C. W., Santoso, W. D., Yulianti, M., Herikurniawan, H., ... \& Yunihastuti, E. (2020). Coronavirus disease 2019: Tinjauan literatur terkini. Jurnal Penyakit Dalam Indonesia, 7(1), 45-67. 
Wahyudi, I., Bahri, S., \& Handayani, P. (2019). Aplikasi Pembelajaran Pengenalan Budaya Indonesia. Jurnal Teknik Komputer, 5(1), 71-76.

World Health Organization. (2020). Frequently asked questions: breastfeeding and COVID-19: for health care workers, 12 May 2020 (No. WHO/2019-nCoV/FAQ/Breast_feeding/2020.1). World Health Organization.

Yuliana, W., \& Hakim, B. N. (2020). Emodemo Dalam Asuhan Kebidanan Masa Nifas. Yayasan Ahmar Cendekia Indonesia.

Yuliaty, T., Rambe, A., Zulfendri, Z., \& Satria, B. (2021). Kebijakan Karantina Kesehatan Dalam Upaya Mencegah Penularan Corona Virus 19 Di Kota Medan. Jurnal Pembangunan Perkotaan, 9(1), 1-8.

Zhou, J., Havens, K. L., Starnes, C. P., Pickering, T. A., Brito, N. H., Hendrix, C. L., ... \& Smith, B. A. (2021). Changes in social support of pregnant and postnatal mothers during the COVID-19 pandemic. Midwifery, 103, 103162. https://doi.org/10.1016/j.midw.2021.103162 